\title{
PERAN MEDIA DALAM PEMBELAJARAN SENI BUDAYA DAN KETERAMPILAN DI SEKOLAH DASAR
}

\author{
Daryanti $^{1}$, Desyandri ${ }^{2}$, Yanti Fitria ${ }^{3}$ \\ Universitas Negeri Padang, Sumatera Barat, Indonesia ${ }^{1,2,3}$ \\ E-mail : daryantiweng4@gmail.com, desyandri@fip.unp.ac.id, yanti fitria@ fip.unp.ac.id
}

\begin{abstract}
Abstrak
Media dalam pembelajaran seni dan budaya sangat dibutuhkan. Pembelajaran seni budaya dan keterampilan merupakan pelajaran yang dapat membangun kreativitas peserta didik bekal kehidupannya kelak. Muatan pelajaran yang ada dalam seni budaya dan ketermpilan tidak hanya mengembangkan kemampuan kognitif, seharusnya mampu mengembangkan afektif dan psikomotornya juga. Dalam lagu, tari dan seni rupa akan dapat mengembangkan karakter bangsa sebagai tujuan pendidikan nasional. Permasalahan ketidakmampuan pendidik dalam melasanakan pembelajaran ini hingga yang terukur hanya kognitif dapat diatasi dengan menggunakan media pembelajaran. Metode yang digunakan pada artikel ini adalah Iliteratur review.
\end{abstract}

Kata Kunci: Pembelajaran,Seni budaya dan keterampilan,Media.

\begin{abstract}
Media in learning arts and culture is needed. Learning art and culture and skills are lessons that can build the creativity of students in the future. The content of existing lessons in cultural arts and skills not only develop cognitive abilities, they should be able to develop affective and psychomotor as well. In songs, dance and fine arts will be able to develop the character of the nation as the goal of national education. The problem of the inability of educators to carry out learning so that only cognitive can be measured can be overcome by using learning media. The method used in this article is literature review
\end{abstract}

Keywords: Learning, Art and culture and skills, Media.

@Edukasi: Jurnal Ilmu Pendidikan FIP UPTT 2019

\begin{tabular}{ll}
\hline$\square$ Corresponding author : \\
Address $\quad$ : Jambak jalur V Timur Pasaman Barat \\
Email $\quad$ : daryantiweng4@gmail.com \\
Nomor HP & $: 081363122193$
\end{tabular}

ISSN 2656-8063 (Media Cetak) ISSN 2656-8071 (Media Online) 
216 Peran Media dalam Pembelajaran Seni Budaya dan Keterampilan di Sekolah Dasar - Daryanti, Desyandri, Yanti Fitria

\section{PENDAHULUAN}

Seni merupakan sesuatu yang fitrah dalam diri manusia. Seluruh perilaku yang ada dalam diri manusia seperti bicara, bernyanyi, marah, tersenyum yang merupakan ekplorasi dari emosional dan intelektual adalah bagian dari seni(Rin Surtantini, 2016)

Dalam kehidupan sehari-hari berdampingan dengan manusia - manusia lain, kita menggunakan seni dalam memaknai sesuatu. Untuk memahami kehidupan ini kita menggunakan seni. Karena seni memang milik semua manusia (Rin Surtantini, 2016) . Siapa pun orangnya, berapa pun umurnya, manusia tetap memiliki seni. Fitrahnya seni itu melekat dalam diri manusia.

Seni sangat melekat dalam kehidupan manusia sehari-hari. Dalam mendidik karakter seni menjadi alat penyampainya. Baik dalam seni suara, seni tari, ataupun seni rupa. Dalam dendang atau tembang pendidik didaerah Jawa menanamkan nilai luhur lewat tembang dan lagu bagi anak-anak, khususnya usia sekolah taman kanak-kanak dan sekolah dasar. Karena tembang dan lagu-lagu Jawa disetiap daerah, didalamnya terkandung ajar-ajaran budi luhur, sementara anak usia sekolah Tk dan SD ibarat kain putih yang masih kosong, sepatutnya dibekali dan ditempa dengan ajaran-ajaran budi luhur membentuk perilaku, sikap, karakter (watak) (Muljono, 2013)

Hal yang sama juga terdapat di daerah Sumatera. Dalam seni suara penanaman karakter terdapat dalam lirik-lirik lagunya. Seperti yang terdapat dalam lagu daerah Minangkabau, hal ini selaras dengan pandapat yang mengatakan lagulagu Minang yang mengandung nilai-nilai dan menggambarkan kondisi realitas yang terjadi di masyarakat.
Nilai-nilai tersebut dijadikan sebagai pedoman dalam melahirkan tindakan dan perilaku yang mencerminkan karakter orang Minang.(Desyandri, Achmad Dardiri, 2015)

Dalam seni tari ditanamkan karakter toleransi sebagai dasar dalam kehidupan berbangsa dan bernegara yang majemuk ini. Untuk menciptakan tarian kelompok yang serasi dalam gerak ,musik dan teman sekelompok dibutuhkan tolerasi. Karakter ini yang sangat berguna bagi siswa dalam kehidupannya. Pada seni tari berkelompok inilah siswa dilatih hidup bertoleransi.(Rosala, 2016)

Begitu pentingnya seni untuk digali dan dikembangkan. Karena dengan pendidikan seni mampu membentuk karakter sesuai dengan Undang-undang Sisdiknas tahun 2003 menyatakan bahwa tujuan pendidikan nasional antara lain mengembangkan potensi didik untuk memiliki kecerdasan, kepribadian, dan akhlak mulia.(Muljono, 2013)

Pendidikan seni dan keterampilan memiliki tempat yang sangat penting dalam masa pendidikan dasar seperti yang disampaikan berikut ini sekolah dasar adalah usia yang paling bermakna dalam kehidupan seorang anak. Oleh karena itu, proses kegiatan seni sebagai bagian dari aktivitasbermain, terutama di sekolah dasar dan taman kanak-kanak, akhirnya menempati kedudukan dan posisi yang strategis dalam pendidikan umum. Hal ini disebabkan pada usia tersebut pertumbuhan dan perkembangan seorang individu disebut sedang mengalami "masa keemasan" (golden period)(Ambarwangi, 2013) 
217 Peran Media dalam Pembelajaran Seni Budaya dan Keterampilan di Sekolah Dasar - Daryanti, Desyandri, Yanti Fitria

Selain hal tersebut tentang pentingnya pendidikan seni itu selaras dengan pendapat Suhaya( 2016) pendidikan seni baik seni rupa, seni musik, seni tari maupun drama seharusnya dapat menjadi wadah atau sarana bagi anak untuk mengembangkan dan menuangkan kreativitasnya. Kebutuhan akan kreativitas bagi anak tidak hanya bagi kehidupan seninya saja tetapi juga dalam kehidupannya sehari-hari, kreativitas memiliki peranan yang sangat penting. Kreativitas bukan hanya kemampuan untuk menciptakan tetapi lebih dari itu yaitu meliputi kemampuan membaca situasi, kemampuan beradaptasi dengan lingkungan, kemampuan membuat analisis yang tepat, serta kemampuan untuk menciptakan sesuatu yang baru yang lain dari pada yang lain.

Begitu pentingnya peran pendidikan kesenian di tingkat dasar. Tetapi banyak kendala yang menyebabkan pembelajaran kesenian cendrung menjadi pelajaran yang hanya bersifat kognitif. Seharusnya denganpembelajaran seni dan budaya mampu mengasah sesorik halus dari peserta didik sebagai dasar untuk mengembangkan keilmuaannya pada masa yang akan datang dari rentang usia yang akan dihadapi oleh peserta didik.

Banyak penelitian yang telah membahas tentang berbagaicara untuk dapat melakukan pendidikan kesenian dan kebudayaan baik dari tingkat taman kanak-kanak sampai ke perguruan tinggi. Dari pendidikan umum sampai kependidikan vokasi. Dari kondisi peserta normal hingga disabilitas.
Ketidakmampuan dalam memaksimalkan pembelajaran ini dilandasi kelemahan seorang pendidik akan mempengaruhi terhadap peserta didik. Rendahnya pengembangan kreatifitas peserta didik lebih banyak disebabkan oleh ketidakmampuan guru dalam mengembangkan kreativitas siswa. Dan pandangan berbagai pihak terhadap pelajaran seni. Keadaan ini lebih diperburuk dengan kekurang mantapan keterampilan dalam berkarya seni dan minimnya wawasan guru terhadap materi, tujuan dan hakikat pendidikan seni, serta kurangnya sarana yang ada di sekolah.( 2009)

Tetapi kemajuan tehnologi dan sebagai seorang yang profesional, pendidik harus mencoba memanfaatkan kemajuan tehnologi tersebut kedalam pembelajaran seni. Peserta didik harus dikembangkan seninya dengan berbagai cara dan sesuai dengan zamannya.

Pembelajaran pada dasarnya adalah suatu kegiatan yang terdiri dari pendidik, peserta didik serta sarana dan prasaran. Sementara itu hakikat belajar mengajar dalam kegiatan belajar mengajar anak sebagai subjek dan objek dari kegiatan pengajaran karena itu inti proses pengajaran tiada lain adalah kegiatan belajar anak didik dalam mencapai suatu tujuan pengajaran.

Tujuan pengajar tentu saja akan tercapai jika anak berusaha aktif mencapainya. Keaktifan anak disini tidak hanya dituntut dari segi fisik tetapi dari segi kejiwaan, bila hanya fisik yang aktif tetapi pikiran dan mentalnya kurang aktif maka kemungkinan besar tujuan pembelajaran tidak akan tercapai.(Purnomo et al., 2016) ${ }^{\mathrm{i}}$ Pembelajaran yang bermakna itu dapat terjadi apabila setiap kegiatannya dirancang untuk membantu peserta didik dalam mempelajarai kemampuan atau nilai tertentu yang menjadi kompetensi dasar dari sebuah mata pelajaran. 
218 Peran Media dalam Pembelajaran Seni Budaya dan Keterampilan di Sekolah Dasar - Daryanti, Desyandri, Yanti Fitria

Indikasi pembelajaran yang kita laksanakan akan dapat dikatakan berhasil jika kegiatan yang berlangsung di sekolah kita tersebut itu mampu memfasilitasi peserta didik dalam proses transfer of value dalam konteks pembentukan karakter bangsa (nation character building) sebagaimana yang tercantum dalam kurikulum resmi.(Purnomo et al., 2016). Serta mampu mengembangkan keterampilan pada diri peserta didik sebagai modal dalam hidupnya kelak.

Keselarasan antara ketiaga aspek pendidikan kognitif, afektif dan psikomotor perlu dilakukan. Ketidak seimbangan akan menyebabkan dampak yang tidak baik bagi peserta didi, masyarakat dan bangsa. Jika hal tersebut tidak dapat kita laksanakan maka hal ini mengakibatkan keruntuhan moral pada masyarakat modern.(Rohidi, 2014)

Pembelajaran yang kita lakukan seyogyanya dapat membuat perubahan pada diri peserta didik sekecil apapun. Jika pembelajaran tersebut hanya berupa transfer ilmu bersifat kognitif itu tidak akan bertahan lama, karena hanya berupa hafalan ini sama halnya dengan anak didik tidak belaja. Peserta didik tidak merasakan perubahan dalam dirinya.

Padahal belajar pada hakikatnya adalah "perubahan" yang terjadi pada seseorang setelah berakhirnya melakukan aktivitas belajar. Sama halnya dengan belajar, mengajar pun pada hakikatnya adalah suatu proses yaitu proses mengatur, mengorganisasi lingkungan yang ada sekitar anak sehingga dapat menumbuhkan dan mendorong anak didik melakukan proses belajar.

Pada tahap berikutnya mengajar adalah proses memberikan bimbingan / bantuan kepada anak didik dalam melakukan proses belajar.(Nana Sudjana1991:29).
Akhirnya bila belajar adalah "perubahan", maka hakikat belajar mengajar adalah prosesditandai dengan aktivitas anak didik sebagai konsekuensi bahwa anak didik merupakan syarat mutlak bagi berlangsungnya kegiatan belajar mengajar, peran guru sebagai pembimbing harus memotivasi “ pengaturan' yang dilakukan guru.

Komponen komponen belajar mengajar, sebagai suatu sistem tentu saja kegiatan belajar mengajar mengandung sejumlah ciri ciri belajar mengajar sebagai suatu proses pengaturan kegiatan belajar mengajar tidak terlepas dari ciri-ciri tertentu menurut Edi Suardi sebagai berikut: 1) belajar mengajar memiliki tujuan yakni membentuk anak didik dalam suatuperkembangan tertentu, 2) ada suatu prosedur (jalannya interaksi) yang direncanakan, didesain untuk mencapai tujuan tertentu, 3) ditandai dengan satu penggarapan materi yang khusus, 6) dalam kegiatan belajar mengajar membutuhkan disiplin, disiplin dalam kegiatan belajar mengajar diartikan sebagai suatu pola tingkah laku yang diatur sedemikian rupa menurut ketentuan yang sudah ditaati, 7) ada batas waktu, untuk mencapai tujuan pembelajaran tertentu batas waktu menjadi salah satu yang tidak bisa ditinggalkan. Setiap tujuan akan diberi waktu tertentu kapan tujuan itu sudah kegiatan diatas masalah evaluasi bagian yang tidak bisa diabaikan setelah melaksanakan kegiatan belajar mengajar evaluasi harus dilakukan untuk mengetahui tercapai tidaknya tujuan pengajaran yang telah ditentukan Keberhasilan belajar mengajar untuk pelajaran Seni Budaya dan Keterampilan. 
219 Peran Media dalam Pembelajaran Seni Budaya dan Keterampilan di Sekolah Dasar - Daryanti, Desyandri, Yanti Fitria

Seni budaya dan keterampilan (SBK) adalah pelajaran yang terdapat pada kurikulum 2006. Yang pada kurikulum 2013 berganti nama menjadi seni budaya dan prakarya(SBdP). Dalam Kurikulum tingkat satuan pendidikan (KTSP) tahun 2006 pendidikan kesenian di SD/MI dilaksanakan melalui mata pelajaran seni budaya dan ketrampilan, yang di dalamnya mencakup sub mata pelajaran seni rupa, seni musik, seni tari, dan ketrampilan.(Utomo, 2010)

Pembelajaran seni budaya dan keterampilan telah disusun secara sistematis . Dengan harapan dapat meningkatkan kecerdasan moral. Hal tersebut telah termuat dan diamanatkan dalam Standar Pendidikan Nasional Nomor 19 tahun 2005. Karena itu mata pelajaran Seni Budaya dan Keterampilan pada dasarnya merupakan pendidikan seni yang berbasis budaya.(EningWidaningsih, 2005)

Bidang Seni Rupa, musik, tari, dan keterampilan memiliki kekhasan tersendiri. Sesuai dengan kaidah keilmuan masing-masing. Aktivitas berkesenian harus menampung kekha san tersebut yang tertuang dalam pemberian pengalaman mengembangkan konsepsi, apresiasi, dan kreasi. Semua ini diperoleh melalui upaya eksplorasi elemen, prinsip, proses, dan teknik berkarya dalam konteks budaya masyarakat yang beragam. Karakteristik belajar siswa seperti kita ketahui bersama pertama karakteristik kognitif yang berhu bungan dengan cara berpikir yang has, kedua karakteristik psikomotor berhubungan cara bertindak yang has. Ketiga karakteristik afektif yaitu cara cara yang has dalam merasakan atau mengungkapkan emosi.(EningWidaningsih, 2005)

Akhir dari pelajaran SBK di tingkat SD/MI untuk seni musik adalah : 1) mengapresiasi dan mengekspresikan karya seni musik dengan memperhatikan dinamika melalui berbagai ragam lagu daerah dan wajib dengan iringan alat musik sederhana daerah setempat; 2) mengapresiasi dan mengekspresikan karya seni musik dengan ansambel sejenis dan gabungan terhadap berbagai musik/wajib, daerah, dan nusantara; dan 3) mengapresiasi dan mengekspresikan karya seni musik dengan menyanyikan lagu wajib, daerah, dan nusantara dengan memainkan alat musik sederhana daerah setempat(Triyanto, 2014)

Media pembelajaran yang bagus merupakan salah satu sarana penting penunjang pendidikan, dengan majunya teknologi saat ini menawarkan pembaharuan dalam pembuatan media pembelajaran. Salah satu bidang penting adalah pembelajaran seni dan budaya yang sangat beranekaragam di Indonesia, di mana saat ini mengalami penurunan antusiasme dari generasi muda untuk mempelajarinya. Hal ini dikarenakan media pembelajaran yang sama masih berbentuk 2 dimensi pada buku-buku pelajaran yang telah umum. (Rosadi \& Purnomo, 2018)

Pembelajaran seni budaya sangat memerlukan penggunaan media dalam pelaksanaanya. Sehingga tidak menimbulkan kejenuhan dan miskonsepsi . Pentingnya penggunaan media yang bersifat kekinian seperti komputer juga telah diungkapkan dalam penelitian Sania Mumtaz( 2000) The factors that were found to be the most impor tant to these teachers in their teaching were: making the lessons more interesting, easier, more fun for them and their pupils, more diverse, more motivating for the pupils and more njoyable. Additional more personal factors were: improving presentation of materials, allowing greater access to computers for personal use, giving more power to the teacher in the school, giving the teacher more prestige, making the teachers' administration more efficient and providing pro fessional support 
220 Peran Media dalam Pembelajaran Seni Budaya dan Keterampilan di Sekolah Dasar - Daryanti, Desyandri, Yanti Fitria

through the Internet.

\section{METODE}

Metode penelitian yang digunakan pada penulisan ini adalah literatur review. Dilakukan untuk menyelesaikan permasalahan-permasalahn yang terjadi pada pembelajaran Seni Budaya dan Keterampilan di sekolah dasar.

\section{HASIL DAN PEMBAHASAN}

Pembelajaran Seni Budaya dan Keterampilan Seyogyanya mendapatkan perlakuan yang le bih,minimalnya sama dari keseluruhan mata pelajaran ataupun muatan pembelajaran yang ada di sekolah dasar. Hal ini penting dilakukan karena peran penting dari pendidikan seni pada usia sekolah dasar. Usia peserta didik pada bangku sekolah dasar adalah usia emas dari pembentukan pola fikir dan karakter.

Pendidikan seni dan budaya sanngat penting dikembangkan dan dikemas di sekolah dasar sebaik mungkin. Dengan belajar seni pesanpesan karakter yang terdapat dalam liri, gerak serta goresan dari alam akan perlahan menanamkan karakter pada diri peserta didik.

Pemikiran tentantang penilaian yang menitik beratkan hanya pada kognitif pada pendidikan formal menyebabkan hanya pembentukan generasi yang cerdas tetapi krisis pada karakter yang dibutuhkan bangsa.(Wardani, 2010). Dengan pendidikan seni yang dilaksanakan dari sekolah dasar dengan maksimal maka terbentuklah sikap yang menjadi penyeimbang intelektualdan kepakaan sosial. Usia yang penuh skap kejujuran sebagai anugerah dari sang pencipta , masa tumbuh kembang yang maksimal dapat dikembang dan dibentuk karakternya melalui pendidikan seni musik, tari dan rupa. Dengan pendidikan seni tersebut semua kreativitasnya dapat dikembangkan.(Suhaya, 2016)
Permasalah ketidakmampuan pendidik dalam pengembangan pembelajaran seni dan budaya karena merasa tidak menguasainya dapat diselasaikan dengan memanfaatkan media pembelajaran. Baik media cetak ataupun media dengan memanfaatkan kemajuan dari tehnogi.

Ketidakmampuan pendidik terhadap seni pun dapat diselesaikan dengan belajar bersama denngan teman sejawat. Belajar bersama dengan teman yang telah mapu dalam pembelajaran lesson study.(Fitriani, 2014)

\section{KESIMPULAN}

Pembelajaran Seni dan budaya harus mendapatkan perlakuan yang sama dalam pembelajarannya oleh para pendidik. Dengan pembelajaran pelajaran seni dan budaya yang meksimalkan kreativitas yang terjembatani pembentukan karakter. Diharapkan dengan pembelajaran seni yang melibat kan seluruh kompetensi yang ada dalam diri peserta didik permasalahan yang timbul disebabkan oleh karakter dapat dikurangi dari kinerja seorang pendidik disekolah dasar.Krisis multidimensi dan keterpurukan bangsa, pada hakekatnya bersumber dari jati diri, dan kegagalan dalam mengembangkan pendidikan karakter bangsa. Permasalahan yang ada dalam diri pendidik dan sarana serta prasaran yang kurang memadai dari lingkungan pendidik untuk melaksanakan pendidikan seni ini, dapat diselesaikan dengan banyak cara.

\section{DAFTAR PUSTAKA}

Ambarwangi, S. (2013). Pendidikan Multikultural Di Sekolah Melalui Pendidikan Seni Tradisi. Harmonia - Journal of Arts Research and Education, 13(1). https://doi.org/10.15294/harmonia.v13i1.253 5

Desyandri, Achmad Dardiri, K. S. A. (2015). Nilai-Nilai Edukatif Lagu- Lagu Minang Untuk Membangun Karakter Peserta Didik 
221 Peran Media dalam Pembelajaran Seni Budaya dan Keterampilan di Sekolah Dasar - Daryanti, Desyandri, Yanti Fitria

(Analisis Hermeneutik) 1)Desyandri,. 3(2), 126-141.

EningWidaningsih. (2005). PembelajaranSeni Budaya Dan Keterampilan Menumbuhkan Kecerdasan Moral Secara Kompetitif.

Fitriani, Y. (2014). Model Pembelajaran Seni Musik melalui Lesson Study : Resital.

Muljono, U. (2013). Pendidikan Nilai Luhur Melalui Tembang (Lagu) Dolanan Anak. $1(1)$, $100-112$ https://doi.org/10.24821/selonding.v1i1.67

Mumtaz, S. (2000). Factors affecting teachers' use of information and communications technology: A review of the literature. Journal of Information Technology for Teacher Education, 9(3), 319-342. https://doi.org/10.1080/14759390000200096

Pengembangan Materi Pembelajaran Seni Musik Berbasis Seni Budaya Berkonteks Kreatif, Kecakapan Hidup, Dan Menyenangkan Bagi Siswa SD/MI. (2009). Harmonia - Journal of Arts Research and Education. https://doi.org/10.15294/harmonia.v9i2.638

Purnomo, F. A., Maret, U. S., Pratisto, E. H., Maret, U. S., Sahrul, F., Lestari, I. P., \& Maret, U. S. (2016). Pembuatan Game Edukasi "Petualangan Si Gemul" Sebagai. Pembuatan Game Edukasi "Petualangan Si Gemul" Sebagai Pembelajaran Pengenalan Daerah Solo Raya Pada Anak.

Rin Surtantini. (2016). Pembelajaran Seni Bahasa Dalam Konteks Lintas Kurikulum Melalui Drama. Jurnal Kajian Seni. https://doi.org/10.22146/art.11650

Rohidi, T. R. (2014). Pengembangan Media Pembelajaran Pendidikan Seni Budaya Berbasis Kearifan Lokal (Wayang Sebagai Sumber Gagasan). Imajinasi - Jurnal Seni, $7(1), 1-8$.

Rosadi, M. E., \& Purnomo, I. I. (2018). Rancang Bangun Media Pembelajaran Seni Dan Budaya Suku Banjar Berbasis Augmented Reality. Jtiulm.

Rosala, D. (2016). Pembelajaran Seni Budaya Berbasis Kearifan Lokal. 2(1), 17-26.

Suhaya. (2016). Pendidikan Seni Sebagai Penunjang Kreatifitas. Jurnal Pendidikan dan Kajian Seni.

Triyanto. (2014). Pendidikan seni berbasis budaya. Imajinasi: Jurnal Seni.

Utomo, U. (2010). Model Pengembangan Materi Pembelajaran Seni Musik Di Sd/Mi
Berdasarkan Kurikulum Tingkat Satuan Pendidikan (Ktsp). Jurnal Penelitian PendidikanA \& A (Semarang), 27(2). https://doi.org/10.15294/jpp.v27i2.176

Wardani, K. (2010). Peran Guru Dalam Pendidikan Karakter Ki Hadjar Dewantara. Proceedings of The 4th International Conference on Teacher Education, (November). 